DUPCSIK CSABA ${ }^{1}$

\title{
FURCSA PÁROK, MOBILOS ANYÁK ÉS SAJÁT-KULTÚRÁS VESÉK
}

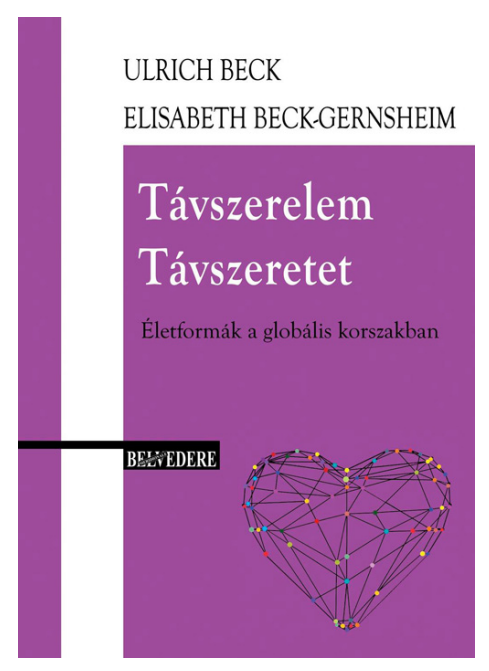

Beck, Ulrich - Beck-Gernsheim, Elisabeth (2016)

Távszerelem/Távszeretet: Életformák a globális korszakban

Ford. G. Klement Ildikó.

Szeged: Belvedere Meridionale

DOI: 10.18030/sOclO.HU.2017.1.71

A recenzált mư ${ }^{2}$ egy jól múködő családi vállalkozás terméke, amelyben a házaspár-munkatársak kombinálták részben egymást átfedő, részben egymást kiegészítő szakértelmüket. Képletszerűen leegyszerúsítve:

Ulrich Beck (késő modernitás- és globalizáció-tematika) + Elisabeth Beck-Gernsheim (család-téma) = (egy család) + a Távszerelem.

Ez a mú ráadásul organikusan sarjadt ki közös életükből, amelynek nyilvánvalóan állandó része volt az együttgondolkodás. ${ }^{3}$ A Távszerelem első oldalán (11) hivatkozott közös könyvükben (címét talán így lehetne fordítani: A szerelem természetes káosza, Beck-Beck-Gernsheim 1994), 13, egyikük vagy kettőjük által írt/szerkesztett müre hivatkoznak; Elisabeth Beck-Gernsheim egy későbbi, egyedül írt múvében (2002) már 17-re. A Távszerelem esetében ezen „mutató” értéke már 20.

A kötet címe, bármily egyszerűnek tűnik, kihívás elé állítja a magyar fordítót: az eredeti Fernliebe kifejezésben ugyanis a Liebe egyszerre jelent szerelmet és szeretetet. A magyar kiadás alkotói a távszerelem/távszeretet formát csak a címben használják, a továbbiakban pedig leggyakrabban a távszerelmet. Talán érdemes lett volna, egy terminológiát magyarázó előszó után,

- a távvonzalom kifejezését használni olyankor, amikor nem egyértelmű, melyik érzelemtípusról van szó, amelyet

- a távszerelem válthatott volna olyan szövegkörnyezetben, amelyről egyértelmű, hogy párkapcsolatról, illetve

1 MTA Társadalomtudományi Kutatóközpont Szociológiai Intézet; Károli Gáspár Református Egyetem

2 A továbbiakban Távszerelem; a külön nem hivatkozott oldalszámok erre a kiadásra vonatkoznak. Az eredeti kiadást (Fernliebe: Lebensformen im globalen Zeitalter. Berlin: Suhrkamp, 2011) a rövid címen fogom említeni, ha konkrét szöveghelyre hivatkozom, akkor a Fern betúkombinációt szúrom az oldalszám elé. A szerzőpárt időnként egyszerűen Beckéknek fogom nevezni. A jelen idő használata Ulrich Beck (1944-2015) esetében is szándékos.

3 Lásd ebből a szempontból Beck-Gernsheim előszavát férje posztumusz kiadott utolsó kötetéhez (Beck 2016: vii). 
- a távszeretet kifejezése olyankor, amikor pl. anya-gyerek kapcsolatról van szó. ${ }^{4}$ (Az angol fordítóknak könnyebb lehetett a love hasonló többes jelentése miatt).

A fern előtaggal már több szerencsénk van: akárcsak a magyar megfelelője, ez a kifejezés is utalhat mind fizikai, mind társadalmi-kulturális távolságra. Beckék könyvének igazi kulcsfogalma ugyanis a világcsalád, amelyben, mint látjuk majd, a távvonzalom mindkét jelentésére szükségük van. Saját megfogalmazásukban: „Két alapvető típust lehet megkülönböztetni. Távszerelem és világcsalád alatt elöször olyan párokat és családokat értünk, amelyek tagjai egymástól elválasztva, másik nemzetben [sic - DCs] és másik kontinensen élnek közös életet, de származási kultúrájuk (a nyelv, útlevél, vallás) azonos (multilokális világcsaládok). (...) A másik esetben távszerelem ${ }^{5}$ és világcsalád alatt olyan párokat és családokat értünk, aki [sic - DCs] egyazon helyen élnek együtt, de a közösségek tagjai különböző országokból, vagy kontinensröl származnak, és a szerelemröl és a családról vallott felfogásukat a származási kultúrájuk határozza meg... (multinacionális, ill. multikontinentális világcsalád). A világcsaládok mindkét változata egyforma azonban abban, hogy ezekben a családokban szó szerint megtestesülnek a globalizált világ különbségei. A szerelmesek, vagy a családtagok akár akarják, akár nem, saját életük belvilágában konfrontálódnak a világgal” (25, Fern 26).

36 oldallal később némileg szabatosabban fogalmazzák újra a lényegi distinkciót: „Világcsaládok létezhetnek két különböző formában. Az egyik csoport ismérve, amiről eddig szó volt, a földrajzi távolság, tehát az a tény, hogy a szerelmespárok, vagy családtagok különböző helyen laknak, különböző országokban. A második csoport jellemzője a kulturális távolság. A családtagok ugyanabban a házban, ill. háztartásban élnek, de kulturálisan (etnikailag...) nagyon különböző kapcsolatrendszerben élnek, következésképpen nagyon különböző tapasztalataik és elvárásaik vannak, beleértve, melyeket személyes életformájuk következtében szereznek, többek között a szerelemmel, házassággal, boldogsággal kapcsolatban” (61). A világcsalád nagyon különböző típusokat magába foglaló kategóriáját a szerzők a nemzeti család fogalmával állítják szembe.

Bár a szerzőknek tetszik saját „egyszerü és könnyen érthető definíciójuk” (25), azt is érezhetik, hogy kulcsfogalmaik, még jóindulatú megfogalmazás szerint is, némileg lazák. Az első meghatározás után azonnal reflektálnak a nehezen besorolható „problémás” esetekre is, mint például: mi a helyzet a másod-/harmadgenerációsokkal? „Hogy az ilyen eseteket világcsaládnak tekintjük-e, attól függ, hogy határokon, illetve kontinenseken átívelő aktív egzisztenciális kapcsolatot ápolnak-e a »másik« származási kultúrájukkal” (kiemelés az eredetiben, 25). Példaként az ulmi unokával skype-on keresztül rendszeresen kommunikáló isztambuli nagyszülőket hozzák.

A fenti példa ezer sebtől vérzik, ${ }^{6}$ a szerzők csak két mondatot szánnak rá, és sietnek új példát hozni: „És hova sorolnánk be Susant és Lizt...?” (26). Két lányról van szó, akik angol anyjukkal Lancesterben élnek, anglikánok, a helyi angol dialektust beszélik, s a még a gyerekkorukban lelépett pakisztáni apjukkal, annak hazájával vagy kultúrájával semmilyen kapcsolatuk nincs (vö. előző bekezdés, ill. 6. lábjegyzet). Elfelejteni a félig pakisz-

4 Néhány esetben, amikor a szerzők egy mondaton belül utalnak a vonzalom e két típusára, akkor a magyar fordító is a távszerelem és a távszeretet váltogatására kényszerül (Id. pl. 14. lábjegyzet) - de tipikusan az előbbit használja általános értelemben is.

5 A kifejezés mindkét előfordulása az idézetben jól illusztrálja, amit fent írtam a problematikus fordításról.

6 Mit jelent pontosan az „aktív egzisztenciális kapcsolat”? A skype és internet előtti korban, ha a nagyszülők nem Isztambulban, hanem egy anatóliai kis faluban éltek, telefon nélkül, s csak átlag évente válthattak szót az unokával - már nem számítottak „világcsaládnak”? Miért van az, hogy az első generációsoknál csak a „kulturális idegenség” számít, a „kapcsolattartás” nem fontos? És hogy illeszthető össze ez a gondolatmenet a közvetlenül utána következő „Susan és Liz”-példázattal? 
táni eredetet? Susannek ez könnyen sikerülhet, írják a szerzők, mert angol anyjára hasonlít, míg „Lis [sic - DCs] tiszta apja, sötét a böre és fekete a haja, ezért mindig a származását firtatják, sértegetik és »pakinak csúfolják. (...) Liz a biológia, ill. a genetika véletlene folytán, amely összekapcsolódik környezete sztereotípiáival és elöitéleteivel, bizonyos értelemben egy világcsalád tagja lett" (26).

A recenzens szerint itt következhetnének az igazán izgalmas kérdések, például: hogyan, milyen identitásstratégiákkal reagál sajátos helyzetére Liz? El tudom képzelni róla, hogy későbbi életében olyan mikromiliőbe kerül, ahol senki sem „firtatja” származását; de lehet, hogy éppen ebben a miliőben egy pozitivan vállalt kettős, brit-pakisztáni identitást alakít ki; vagy az is elképzelhető, hogy egy határozott pakisztáni (vagy muszlim) identitást vállal fel. Elképzelhető, hogy átmeneti, kombinált, vagy szituatíve váltogatott identitásokkal próbálkozik, elképzelhető, hogy életének lesz egy fordulópontja (egy külföldi munka, egy párkapcsolat, gyerek, stb.), amely az identitásaiban is radikális változást hoz. Sőt, tulajdonképpen a felsorolt lehetőségek mindegyike akár Susannel kapcsolatban is elképzelhető, miért lenne az ő identitása annyira egyértelmű, ahogy Beckék példázata sugallja? S Liz (vagy Susan) párkapcsolata egy lancesteri angolszász vagy egy Londonban született félkínai vagy egy már brit állampolgár magyar migráns férfival (vagy nővel) vajon melyik esetben válik „világcsaláddá”?

Az izgalmas kérdések folytatódhatnának egy elvonatkoztatási szinttel feljebb: hogyan alakulnak csoporthovatartozások a társadalom minősítése és az egyéni identitások eredőjeként (amelyet az „objektív” tényezők, mint a származás, a kinézet vagy az anyanyelv természetesen nem „determinálnak”, az utolsó idézett mondat ebből a szempontból kissé félrecsúszik; bár ettől még igaz, hogy bizonyos látványos jellegzetességek időnként erősen lehatárolhatják az egyének mozgásterét). Mitől lesz valaki „kulturálisan/etnikailag távoli”? - ez lehetett volna az igazán ígéretes kérdésfelvetés.

Az előző bekezdés feltételes módja nem véletlen: Beckék számára „Susan és Liz” példázata nem elméleti megfontolások kiindulópontja, mint inkább annak eszköze, hogy kimutathassák, hogy ők mennyire reflexívek. A „valóság sokkal sokrétübb, tarkább”, mintsem „szép, egyszerü meghatározásunk” sugallja, hangsúlyozzák rögtön a történet után, a két családtípus csak „ideáltipikus fogalmak”, "a világcsalád és nemzeti család nem abszolúte ellentétes, hanem mindkettő egy folyamat végkifejlete, amelynek számtalan közbülső, mellék- és kevert formája létezik" (26).

Sőt, még azt a lehetséges ellenérvet is maguk hozzák fel, hogy „a »család « fogalma a »világcsaládban« ignorálja a családformák pluralitását, amit a kulturálisan homogén életformák esetében már régen felismerték és elfogadták, és amivel már mi is foglalkoztunk a Das ganz normale Chaos der Liebe (1990) c. könyvünkben..." (27). De bocsánat, ez csúsztatás, hisz eddig - és a Távszerelem későbbi oldalain is - nem a családformák pluralitásáról van szó, hanem a családtagok kulturális és/vagy fizikai távolságáról... Az utolsó idézet előfeltételezi, hogy a nemzeti családok „kulturálisan homogén életformák” megnyilvánulásai - noha ez inkább egy érdekes kérdés lenne (mint erre még visszatérek).

Ha a recenzens megpróbálkozik azzal, hogy rendszerezze Beckék kulcsfogalmának változatait, akkor talán a következő módon tudná ábrázolni (1. ábra). 


\section{1. ábra. A Távszerelem ideiglenes világcsalád-tipológiája}

\begin{tabular}{|l|l|l|}
\hline & Kulturális távolság & Földrajzi távolság \\
\hline Párkapcsolatok & "interkulturális világcsalád” & "multilokális világcsalád”(„távszerelem”) \\
\hline Leszármazási család & & "multilokális világcsalád” (pl. „mobilos anyák”) \\
\hline
\end{tabular}

Érdemes felfigyelni arra, hogy az 1. ábra bal alsó cellája üres - Beckék gyakorlatilag nem foglalkoznak annak lehetőségével, hogy egy adott családban az egymást követő generációk között kialakulhat a „kulturális másság”. Beckék mintha előfeltételeznék, hogy valaki vagy „távol” (fern) születik és szocializálódik (vagy a még „távol született” szülők végzik az elsődleges szocializációját), 8 így a kultúrája is más, s ha ezt a másságot „magával hozza” egy párkapcsolatba, akkor ezáltal „világcsalád” jön létre; vagy pedig nincs „másság”, amit hozhatna, s akkor automatikusan „kulturálisan homogén (nemzeti) család” alakul ki. Pedig a társadalomtudományos szakirodalom tekintélyes része szerint a kulturális másságot létrehozzák, konstruálják, kreálják, az adott másságot hordozó egyén, illetve közvetlen és tágabb közössége „összjátéka” nyomán. A folyamat következtében pedig kialakulhatnak kulturális törésvonalak is, akár egy-egy családon belül. Közhelyszerű példa az első generációs, muszlim migráns hátterû európai család, amelyben a szülők többé-kevésbé szekularizáltan, néha görcsösen, akár önfeladás árán is integrációra törekednek, míg az Európában született második vagy harmadik generáció egyszerre felfedezi „eredeti” kulturális/vallási gyökereit. ${ }^{9}$ Az ilyen jelenségek elemzésekor azonban lehet, hogy „az iszlám kultúra” sajátosságai helyett inkább az európai történelmet érdemes tanulmányozni, s olyan analógiákat keresni, amikor fiatalok csoportjai egy-egy nemzedékben ideológiai vagy etnikai alapon új, szüleikétől radikálisan különböző identitást konstruáltak maguknak. Képzeljünk el egy liberális Rajna-vidéki családból származó ifjút, aki 1931-32-ben náci rohamosztagos lesz; egy jiddis anyanyelvű ortodox lengyelországi zsidó családból származó ifjút, aki a 20. század első felében cionista ${ }^{10}$ lesz; egy usztasákkal/nácikkal kollaboráló bosnyák családból származó fiatalt, aki „jugoszláv” kommunista lesz, és így tovább. Az ilyen párhuzamok, meggyőződésem szerint, többet segítenek a másod-/harmadgenerációs, Európán kívüli migráns hátterű családok identitás-fordulatainak megértésében, mint „az ősi kultúra feltámadásának” esszencialista képe.

A „szerelmes állapot: »két ember forradalma«” - idézik a szerzők Alberonit (48). Persze Beckék is látják, hogy egy más kultúrából, más kontinensről választott társ egyúttal a származási csoport számára is üzenet jelleggel bír - de ezt a gondolatot egyrészt pszichologizálják (mintha csak a szerelmesek és családjaik magándrámájáról lenne szó), másrészt esszencializálják. A szőke, kékszemú lübecki fiatalember szenegáli, indiai vagy koreai házastársat választ - ez nyilvánvalóan egyúttal a szülői mintákról való leválásnak egy erősen kihangsúlyozott módja. „»Szerelem« és »leválás", két erős motiváció egyben: micsoda csáberő!” - írják Beckék. Majd váratlanul így folytatják: „Egészen addig a napig, amíg a fiatalok idősebbek lesznek” (50), amikor esetleg a „régi identitás" amolyan zombiként feltámad (ezt értem „esszencializálás” alatt).

7 „Cell-Phone Mum” (119) - a Fülöp-szigeteken született nőket nevezik így, akik külföldön, tipikusan egy másik kontinensen dolgoznak, és mobilon keresztül nevelik gyermekeit.

8 A korábban idézett „mi van a másod-/harmadgenerációsokkal?” kérdésre ez lehet az egyik érdemi válasz, tehát a szocializáció, nem pedig a „kapcsolattartás az eredeti kultúrával”.

9 Miközben, ironikus módon, a fiatalok esetleg, egyes vonásaiban jobban ismerik a befogadó ország kultúráját (például akcentus nélkül beszélik a nyelvet), mint szüleik.

10 Ami a közhittel ellentétben szekularizált, eredetileg baloldali nacionalista ideológia, amivel a zsidóság konzervatívabb csoportjai a holokauszt előtt - sőt, részben azóta is - nem könnyen azonosulnak. 
A fenti gondolatmenet a Meglepetés-effektusok c. alfejezetben olvasható, ahol olyan váratlan - tipikusan mindkét felet váratlanul érő - fordulatokról van szó, amelyben a már elhagyottnak hitt korábbi kultúra elemi erővel revitalizálódik. Beckék Augustin Barbara példáját (1989) hivatkozták: „...[E]gy örmény férfinak francia felesége volt, negyven éve Franciaországban élt, míg egyszer csak fel akarta fedezni a gyökereit, és Örményországba utazott, majd miután hazatért, egyre gyakrabban kezdett örmény zenét hallgatni. Itt a francia feleség, aki muszlim-török származású volt, ugyan már évekkel ezelött megkeresztelkedett, férje meglepetésére hirtelen egyre gyakrabban látogatta családját, és végül elhatározta, hogy betartja a Ramadan hónap böjti elöirásait" (46). A recenzens már arról kezdett spekulálni, hogy egyrészt milyen sajnálatosan keveset tudunk meg ezen örmény-török-francia házasság belső dinamikájáról, másrészt pedig hogy semmit sem tudunk meg az örmény és török kulturális gyökerekkel kapcsolatos nemzetközi diskurzus változásáról sem. ${ }^{11}$ Végül utánanéztem a Beckék által hivatkozott könyvben, s rá kellett jönnöm, hogy kínos tévedés történt: a két ember csak a fenti idézetben túnik házaspárnak, valójában két külön eset volt... (Barbara 1989: 55; a hibát nem a szerzők, hanem a fordító követte el, vö. 46 és Fern 56).

A Távszerelem szerzői kecsesen tovasiklanak az elméleti vékony jégen, és a próbálkozás, bármilyen meglepően hangzik is, bizonyos mértékben „bejön”. „Két nemzet, egy pár: történetek [kiemelés tőlem - DCs] a kölcsönös megértésröl és félreértésekröl" - ilyen a Távszerelem egy fejezetének (29-51) a tipikus címe. S valóban, inkább történeteket olvashatunk, mintsem elemzéseket; történeteket, esettanulmányok, kutatások, interjúk és szépirodalmi művek felidézése révén, az adatokkal inkább csak illusztrálva (nincs a kötetben egyetlen táblázat vagy diagram sem), annak sűrú hangsúlyozásával, hogy lám, ezt teszi a második modernizáció és a globalizáció. Ez a stílus, Beckék könnyed fogalmazásával, és természetesen a szerzőpáros évtizedek alatt felhalmozódott hatalmas reputációjával a háttérben, azt az érzést kelti az olvasóban, hogy megértett valamilyen, napjaink világa szempontjából roppant fontos összefüggést.

E ponton talán nem árt hangsúlyozni: a recenzens még mindig elolvasásra javasolja a recenzált múvet - de sokkal kritikusabb hozzáállást javasol az olvasóknak, mint a Távszerelemmel való első szerelem idején gondolta volna. ${ }^{12}$

A történetek, példák, adatok sorolása tehát egyszerre jelenti a Távszerelem gyenge pontját, de ugyanakkor egyik erősségét is - kár, hogy terjedelmi okokból oly keveset tudok itt idézni. Ízelítőképpen három példa:

1.) Vidéki, agráriumban dolgozó férfiak, akik körében „a helyben maradás, hazaszeretet, ragaszkodás a hagyományokhoz, a »másokkal« szembeni nyiltan vállalt elhatárolódás nagyon jellemző" (93) - azt várnánk, hogy ilyen közegben a legkisebb mértékű a külföldi házastárs választása, de például Dél-Korea ebből a szempontból kivétel. Míg Koreában 1990-ben az összes házasság 1,2\%-ában jött külföldről (tipikusan Kelet- és Délkelet-Ázsiából) az egyik házastárs, addig 2008-ban már 11\% esetében - s ez a változás főleg a paraszti népességnek tulajdonítható (92-93).

11 Egyrészt a Barbara könyvének megjelenését követő években, a felbomló Szovjetunióban aktivizálódott az örmény nacionalizmus, amelynek a kibontakozó karabahi háború nyilván hatalmas emocionális töltetet kölcsönzött. Másrészt, ugyancsak az 1980-as években, a török kormányzat támogatásával egész „tagadás-ipar” fejlődött ki az örmény népirtás körüli diskurzus befolyásolására (Auron 2003: 47).

12 Mindezt irónia nélkül írtam: sokra tartom, elsősorban Ulrich Beck munkásságát, s amikor elhatároztam a megírását, biztos voltam benne, hogy a recenzió dicsérő jellegú lesz. 
2.) Németország, Izrael, Libanon - mi a közös ebben a három országban a Távszerelem kontextusában? Az, hogy a hatóságok szisztematikusan akadályozni próbálják azokat a házasságokat, amelyekből „világcsalád” jöhet létre. Ennek következtében szabályszerű „házassági turizmus” fejlődött ki, évente több ezren utaznak az említett országokból Dániába vagy Ciprusra, házasságkötés céljából (39).

3.) A második világháború idején a brit nők tipikusan „túl rámenősnek” látták az amerikai katonákat, míg utóbbiak „túl könnyen kaphatónak” a brit nőket. A kölcsönös félreértés oka az volt, hogy a két országban eltért egymástól a szexuális közeledést szabályozó nem tudatosított, de roppant fontos kulturális protokoll: az amerikaiak szerint a csók a kapcsolat elején, míg a britek szerint egy későbbi fázisában „szabályszerü”. „Ha az amerikai katona... [viszonylag gyorsan] eljut a nyelves csókig, az angol nő rászedettnek érzi magát, mivel az ö belső ranglétrája szerint a nyelves csóknak közvetlenül... a szexuális behatolás elött kell megtörténnie. A mit sem sejtö brit nőnek a csók után csak a következő alternativája maradt: vagy azonnal megszakítja a romantikus együttlétet (akkor fölösleges volt az egész szerelmi vesződség), vagy odaadja magát" (Watzlawick és társai nyomán: 65).

Érdekesek a Távszerelem azon fejtegetései, amelyek arról szólnak: miközben a - tipikusan szegényebb országokból - Nyugatra házasodó nőket igen gyakran áldozatnak tekintik, ${ }^{13}$ ők igen gyakran aktív ágensek, akik többet nyernek ezen a házassági mobilitáson, mint ha hazájukban kötöttek volna „szokásos” házasságot (103). S ezt hangsúlyozottan nem „csak” a magasabb életszínvonalat jelenti, hanem az individuális mozgástér bővülését, s ezáltal a védettebb méltóságot és az önrendelkezés nagyobb esélyét. „Egy házassági migránsnő anyja... »Korábban, amikor a lányom még nem keresett, sose kérdeztem meg semmiröl... Most, hogy ő támogatja az egész családot... meg kell vele beszélnem minden családi ügyet..." (140).

„Amíg korábban a szerelem bizonyitéka volt, ha a párok együtt maradtak, akármi is történt, úgy most a globalizált világban egyre inkább az ellenkezője a parancsolat: aki szereti a családját, elhagyja azt, hogy máshol teremtse meg egy jobb jövő alapjait" (118). Az így kialakuló távkapcsolatok sokak szerint halálra vannak ítélve - mások szerint manapság, amikor kommunikációra van lehetőség, de a „fullasztó hétköznapok” elkerülhetők, ez a helyzet akár tartósíthatja is az ilyen kapcsolatokat (57). A „távszerelem olyan, mind a szex ágynemümosás nélkül" (57) - érdekes szellemesség, nem biztos, hogy értem... De ha szó szerint veszem, akkor a technikai fejlődés nyomán gyorsan elavulhat: ha majd a szexuális ingerek is továbbíthatóak lesznek az interneten keresztül, az talán „megoldja” a „távszerelem” problémáját (újabb problémák özönét kiváltva közben, természetesen).

A szerzők hasonlóan provokatív álláspontot foglalnak el a „globalizált cselédlányok” Nyugatra áramlásával kapcsolatban is. A világ egyre több pontjáról, ahonnan a 20. század derekán túlnyomórészt férfiak vándorol-

13 „„...[A] házasság céljából útra kelő nők áldozatként jelennek meg... viszonylag ritkábban, ők játsszák a tettes szerepét” (98) - nem lennék meglepve, ha a német közvélemény nyilvánosan nem artikulált bugyraiban sokkal gyakoribb lenne a „tettes”-narrativa, mintsem az a sajtóból vagy a szakirodalomból kitűnik. Utóbbi szektorban viszont az „áldozat”-narrativa egyes megnyilatkozásai még a szerzőket is kritikára ingerlik. Idéznek például egy Németországba házasodott filippino és thai nők körében végzett kutatást. Mivel a megkérdezett nők általában elégedettek voltak házasságukkal és helyzetükkel, és sehogy sem akartak a globális patriarkális kizsákmányolás áldozatainak láttatni magukat, a kutatást végrehajtó négy kutatónő érezhetően zavarba jött. Eredményeik publikálásának idejére azonban már feldolgozták a sokkot: a kutatottak „rezignált magatartásával” magyarázták "hamis megelégedettségüket”, amely valójában „csak önámítás és csak puszta látszat, amely mögött elrejtik valódi érzéseiket” (id. 99). 
tak ki dolgozni, most női többség indul útnak (például a Fülöp-szigetek ${ }^{14}$ kivándorlói között 30 év alatt 12\%-ról 70\%-ra nőtt a nők aránya (20). Igazi paradoxonról van szó, hisz ebbe a mélyen egyenlőtlen helyzetbe a más régiók nőinek millióit éppen a nyugati nők növekvő egyenlősége szívja be. „Tanárnők a Fülöp-szigetekröl, egyetemisták Mexikóból, fordítók Ecuadorból, jogászok Ghánából útra kelnek olyan országokba, ahol a nők napjainkban konszerneket, föiskolákat vezetnek, és politikai pártokat irányitanak, és ott olyan munkákat végeznek, amelyek évszázadok óta női munkának számítanak: takarítanak, föznek, vigyáznak idegen családok gyerekeire, és törődést igénylö öregekre" (19). Mielőtt a nyugati értelmiség egy jelentős részének pavlovi reflexeivel felszabadító küzdelemre szólítanánk fel, nem ártana reflektálni arra, hogy vajon kik ezen globális kizsákmányolás nyugati haszonélvezői, illetve, hogy vajon nyernének-e azzal a vándormunkásnők, ha elvágnák számukra ezt a megélhetési lehetőséget ${ }^{15}$ (115).

(A magyarországi helyzet, természetesen, még vázlatosan sem egy recenzió keretei közé illik, de ízelítőként idézném egy, az interjúja alapján nemrég elvált magyar celeb nő sóhaját: „Igazából egy feleségre lenne szükségem, aki a gyerekekkel foglalkozik, föz, mos, takarít."16 Magyarország, 2017.)

A „világcsalád” néha követhetetlenül tág fogalomnak tünik. Példának okáért, Beckék ide sorolják, amikor egy nyugati család egy „távoli” országban felfogadott béranya segítségével gyarapodik. India a béranyaság központja, itt legalább 350 klinika dolgozik, jórészt „exportra”, s versenyképesek is, mivel csak 12-20 ezer dollárt kérnek olyan szolgáltatásért, amely az Egyesült Államokban 70-100 ezer lenne (160). De ez, bármilyen brutálisan hangzik, csak egy méh bérbevétele, egy egyszeri aktus, amelynek során - a „komplikációk” elkerülése végett - ma már a hivatásos béranyák csak mások embrióit hordhatják ki. Beckék logikája szerint, ha a béranya a saját társadalomból kerül(ne) ki, akkor már nem esne a „világcsalád” hatálya alá - de el nem tudom képzelni, hogy ez esetben a felmerülő etikai, pszichológiai és „biológiai” problémák lényegesen mások lennének.

A szerzők következő témája a tudatosan ismeretlen apa - az USA-ban egymillió, Németországban mintegy százezer gyereket spermadonor "nemzett” (165-166). A téma diskurzusa sokáig szinte kizárólagosan az így teherbe eső nőkre összpontosított - de azóta felnőtt egy ilyen módon nemzett generáció, akik a legújabb kutatások szerint utólag gyakran nehezen dolgozzák fel „gyökereiket” (166-168). De mi köze van ennek a témának a „világcsaládhoz”? Van érdemi különbség annak alapján, hogy „idegen spermáról” vagy „nemzeti spermáról” van szó?

Végképp érthetetlen, hogy kerül a kötetbe a globális szervkereskedelem témája. Ennek következtében „az idegen” testének egy része betű szerint egy távoli másik testének részévé válik (150-170) - bármennyire hatásos képről van szó, biztos, hogy a téma ide tartozik? Egy „nemzeti máj” vagy egy „saját kultúrából származó vese" ritkábban lökődik ki és pszichésen is feldolgozhatóbb?

149 millió Fülöp-szigeteki munkavállaló (10\%) dolgozik külföldön, „többségük gyermekes asszony” (118). „A háztartási munka migránsnőire a férjükkel kapcsolatos »távszerelem " mellett jellemző a hazájukban maradt gyerekeikhez füződő »távszeretet" [is]" (111). Ráadásul a „házimunka migránsait” egy-egy konkrét nyugati családban „egyszerre »kirekesztik és ugyanakkor »befogadják“” (111). Emlékeztetnék rá: e három relációt egyaránt a „világcsalád” kategóriája fedi, ahogy az is „világcsalád” lenne, ha egy migránsnő szakítana otthoni családjával és Nyugaton alapítana új családot - meg az is, ha férje és gyerekei is utána tudnának utazni.

15 A recenzens kicsit élesebben fogalmazta újra a szerzőpáros gondolatait.

16 http://velvet.hu/gumicukor/2017/04/12/demcsak_zsuzsa_igazabol_egy_felesegre_lenne_szuksegem/ 
Vagy vegyünk egy másik, felületes pillantásra problémátlan példát: a Svédországban élő iráni házaspárok a Távszerelem eredeti definíciója szerint akár nemzeti családoknak is tekinthetők, hisz a családon belül nincs se kulturális, se földrajzi távolság, csak a teljes család eredeti és késóbbi lakóhelye között (133-134). Igaz, fontos összefüggés, hogy az ilyen családokban nagyobb a válási mutató, mint az etnikai svéd környezetben: ugyanis „sok bevándorló férfi lecsúszásként éli meg új helyzetét... [míg az iráni] nök felszabadulásként élik meg” (134) ugyanezt. S még ugyanezen az oldalon jön az általánosítás: „ahol a nemek közötti viszony már nincs többé megkérdőjelezhetetlenül köbe vésve, vagyis a tradíció, hanem alapjaiban megrendülve egy kicsit mozgásba lendül [sic - DCs], ott éppen a partnerválasztás lesz a terrénuma a családokon belüli rend újratárgyalásának, aktiv alakitásának" (134).

Nem inkább az egyik lehetséges terrénuma? S itt beleütközünk abba a kérdésbe, amelyet a Távszerelem újra meg újra érint, de sosem elemez végig a kellő gondossággal: biztos, hogy érdemes ilyen módon szembeállítani a „világcsaládokat” és a „nemzeti családokat”? Ha szándékosan félreértem a saját szónoki kérdésemet, akkor máris határozott „nem” a válasz: Beckék konzekvensen összekeverik a világcsaládot a nemzeti társadalmon belüli másságok között kialakult családi kapcsolatokkal. „....[E]gy amerikai nő, aki feketével kötött házasságot...” (51); vagy: „...egyesek a partnerválasztást az elszakadással kötik össze, hiszen egy »máshoz « füződő kapcsolat (egy külföldihez, feketéhez, zsidóhoz, akár egy azonos nemühöz, aki a szülők szemében mindig a másik lesz - [kiemelés tőlem - DCs]) tiltakozást és provokációt, lázadást és saját akaratot fejez ki" (49-50). Érdemes felidézni a korábbi „,házassági turizmus”-példát - Libanonban vagy Izraelben a különböző vallású párok házassága ütközik akadályba, akkor is, ha a pár mindkét tagja „őslakos”.

A világcsaládba lépő „idegen” néha a „külföldivel” azonos, néha kifejezetten a Latin-Amerikától a TávolKeletig húzódó, a hidegháború korában harmadik világnak nevezett zónából érkező migránsokkal és azok leszármazottaival. Néha pedig, meghökkentő könnyedséggel és reflektálatlansággal, egyes - de meg nem határozott - a nemzeteken belüli kisebbségek tagjaival. „[A] világcsaládok magukban hordozzák a világ ellentéteit. (...) A binacionális párok megtapasztalják a két nemzet ellentéteit [kiemelés az eredetiben - DCs], vagy pedig a többségi és kisebbségi társadalom ellentéteit [kiemelés tőlem-DCs]. A migrációs családok megtapasztalják az elsó és a harmadik világ közötti ellentéteket, a globális egyenlötlenségeket, vele együtt gyarmatositásuk történetét, amely a mai napig jelen van az élők lelkében, ami egyeseknél felejtést, másoknál gyülöletet és kétségbeesést vált ki” (18). Az utolsó idézettel a Távszerelem újabb tipikus motívuma jelent meg: miközben a konkrét történetekben újra meg újra találkozhatunk lengyelekkel, ukránokkal, oroszokkal, ${ }^{17}$ addig az általánosításokban a volt „második világ” (Közép- és Kelet-Európa) kipottyan az „elméleti” figyelem keretei közül.

Mitől lennének annyira homogének a „nemzeti családok”, ahogy, Beckék minden „mentegetőzése” ellenére is a fogalom és a világcsaláddal való szembeállítása ${ }^{18}$ sugallja? Lásd Beckék egy példáját: a „déliek” (vagy az észak-amerikaiak) extrovertáltabbak és hangosabbak, mint „a németek”, s ez a kulturális különbség az egyéni

17 S a magyarokkal is - ilyenformán: „Egyesek elutasitják, minden eszközzel harcolnak az árulás ellen, ami a saját (német, magyar, lengyel) nemzetet érte, és a faj és a vér [fordítási szempontból lásd lenn - DCs] ellen irányul” (30).

18 A „származási kultúrájuk (a nyelv, útlevél, vallás) azonos...” - idéztem a recenzió elején (25). Mindezt egy „olyan világban, melyben a kb. 180 államból alig egy tucat állithatja meggyőzően, hogy állampolgárai a szó legszorosabb értelmében egyetlen etnikai vagy nyelvi csoporthoz tartoznak..." (Hobsbawm 1997: 235). Egy svájci német és egy svájci francia házassága „világcsalád”? Egy svájci német és egy németországi német kulturálisan idegenek egymásnak (hiszen kapcsolatuk „binacionális” lenne)? 
interakciók szintjén rengeteg konfliktust, vagy legalábbis félreértést okozhat (42). Az előző mondatba foglalt megállapítást követően a szerzőpár már „egy észak-európai és egy déli” kapcsolatáról ír, s példaképpen Thomas Mann A Buddenbrook-ház c. regényére hivatkoznak. A „legújabb szakirodalom” (Mann regényét 1901-ben publikálták először) szerint tehát a bajorok is „déliek”? De a tréfát félretéve: elég elterjedt toposz arról beszélni, hogy „a németek” gyújtőfogalma alatt a poroszok, a szászok, a Rajna-vidékiek, a bajorok, az 1945 után kitelepített magyarországi svábok, az 1990-es években „hazatérő", irodalmi németet nem vagy csak törve beszélő oroszországi vagy romániai Volksdeutschok, stb. jelentős kulturális különbségek bíró csoportjai húzódnak. S akkor még nem is beszéltünk az ossie-k és wessie-k, tehát a volt NDK-ban, illetve NSZK-ban szocializálódott németek kulturális másságáról. E csoportok tagjai homogén „nemzeti családokat” alkotnak? Míg például egy török bevándorló unokája, akinek már a szülei is Németországban születtek, aki tisztábban beszéli a németet, mint a „bennszülöttek” jelentős része, s akit rasszjegyek sem különböztetnek meg német környezetétől - szülőföldjén csak egy „világcsalád” tagja lehet?

(Hogy a magyar nemzetállamon belül, az etnikai különbségeket nem is számítva milyen látens és nyílt kulturális törésvonalak húzódnak, amelyek gyakran mélyebbek, mint amelyek egyes magyarokat és külföldieket választanak el, azt nyilván nem ebben a recenzióban kellene taglalni.)

Végül: az első olvasás során számos olyan megfogalmazást találtam, amely mögött fordítási problémákat sejtettem, de a magyar és a német kiadás összevetése után kiderült, hogy ezek száma kisebb, mint vártam. A fent már idézett „meglepetés-effektus” (46) például, meglepetésemre tényleg Überraschungeffekte volt (Fern 55). Akadnak természetesen hibák is, pl. a korábban (javítva) idézett "faj és a vár" - a második főnév persze a „vér" elgépelése, de a Rasse (vagy az angol race) „fajnak” fordítása (30, Fern 34), bármennyire gyakori is a hazai szakirodalomban, szerintem hibának tekinthető. Igaz, elismerem, ez megnehezíti az ehhez hasonló mondatok fordítását: „Wir wohnen in einer rassisch gemischten Straße in einer rassisch gemischten Gegend..." (Fern 40) - talán „faji szempontból” lehetne, idézőjelben, vagy magyarul nehézkes rassz-szempontból. De a „Mi egy rasszista szempontból kevert lakosú utcában lakunk, hasonló környéken..." (35) teljes félreértése a mondatnak.

„Kozmopolitán” a kosmopolitisch (77, Fern 97) fordításaként? „A posztmoderni tetszőlegesség nem veszi figyelembe, hogy amint említettük, a nem tetszésszerüségnek létezik védőbástyája: az emberi jogok” (191) - itt nem is annyira a fordítással ${ }^{19}$ van gond, hanem hogy a magyar mondat gyakorlatilag érthetetlen.

A kötet inkább egy alapos szerkesztésre szorult volna rá. Egy jellegzetes hiba: „(lásd fentebb 37)” (40) - ez csak a német kiadásban volt a 37. oldalon (lásd Fern 47), a magyar kiadásban a 32-33. oldalakra kellett volna hivatkozni. Bár nem gyűjtöttem kifejezetten a fogalmazási és egyeztetési hibákat, elgépeléseket, csak a fenti recenzió idézeteibe 4 sic-et voltam kénytelen szúrni.

19 „Dieser Vorwurf der postmodern Beliebigkeit verkennt, daß es, wie gesagt, eine Bastion der Nichtbeliebigkeit gibt: die Menschenrechte” (Fern 249). A tükörfordítás helyett talán inkább az „önkényesség” - „szükségszerüség” szembeállítással kellett volna próbálkozni, ami filozófiailag nem teljes ugyanaz, de mondat eredeti mondanivalóját pontosabban visszaadta volna. 


\section{HIVATKOZÁSOK}

Auron, Y. (2003) The Banality of Denial: Izrael and the Armenian Genocide. New Brunswick: Transaction Publishers.

Barbara, A. (1989) Marriage Across Frontiers. Clevendon - Philadelphia: Multilingual Matters.

Beck, U. - Beck-Gernsheim, E. (1994) Das ganz normale Chaos der Liebe. Frankfurt/M: Suhrkamp Verlag. Angolul: The normal chaos of love. Ford. Ritter, M. - Wiebel, J. Cambridge: Polity Press.

Beck-Gernsheim, E. (2002) Reinventing the family: in search of new lifestyles. Ford. Camiller, P. Cambridge: Polity Press.

Hobsbawm, E. J. (1997) A nacionalizmus kétszáz éve. Ford. Baráth K. Budapest: Maecenas. 